\title{
The Mechanisms of Immune System Regulation by Probiotics in Immune-Related Diseases
}

\author{
Parvin Bastani ${ }^{1}$, Aziz Homayouni ${ }^{2}$, Leila Norouzi-Panahi ${ }^{3}$, Arash Tondhoush ${ }^{4}$, \\ Sharareh Norouzi ${ }^{5}$, ElnazVaghef Mehrabany ${ }^{6}$ and Zahra Kasaie ${ }^{7, *}$
}

${ }^{1}$ Obstetrics and Gynecology, Women's Reproductive Health Research Center, Tabriz University of Medical Sciences, Tabriz, I.R. Iran

${ }^{2}$ Department of Food Science and Technology, Faculty of Nutrition, Tabriz University of Medical Sciences, Tabriz, Iran

${ }^{3}$ Department of Midwifery, Tabriz Branch, Islamic Azad University, Tabriz, I.R. Iran

${ }^{4}$ Department of Food Quality Control, International Branch of Shahid Beheshti University, Tehran, Iran

${ }^{5}$ Department of Food Science and Technology, Faculty of Nutrition, Tabriz University of Medical Sciences, Tabriz, Iran

${ }^{6}$ Department of Food Science and Technology, Faculty of Nutrition, Tabriz University of Medical Sciences Tabriz, Iran. Student Research Committee, Tabriz University of Medical Science, Iran

${ }^{7}$ Food Science and Technology, Shahid Sardari Institute, Ministry of Jehad Agriculture, Tabriz, I.R. Iran

\begin{abstract}
Probiotics are live microorganisms which when administered in adequate amounts, may confer a health benefit on the host. Stimulation and regulation of immune system is among well documented benefits claimed for probiotics. Both innate and adaptive immune system can be regulated by these microorganisms. Effects of probiotics on immune system are significantly dependent on the strain, dosage and the investigated condition. In this article the mechanisms through which probiotics may regulate immune system were reviewed. These mechanisms are consist of blockage of adhesion sites for pathogenic bacteria, competition for nutrients, production of inhibitory compounds, degradation of the toxin receptors in the mucosa membrane, activation of phagocytic and natural killer cells as well as regulation of cellular and humoral immunity. Also the immune-related diseases including immune deficiency (Acquired immunodeficiency syndrome) and hypersensitivity (allergy, inflammatory bowel disease, diabetes mellitus type 1 and rheumatoid arthritis) were discussed.
\end{abstract}

Keywords: Probiotic, immune, regulation, mechanism, Food, disease.

\section{INTRODUCTION}

The word "probiotics" was first used by Elie Metchnikoff in the beginning of the 20th century. It was proposed that adult human body has 10 times more bacterial cells in his gastrointestinal tract than eukaryotic cells in his body [1, 2]. Probiotics are "Live microorganisms which when administered in adequate amounts confer a health benefit on the host" [3, 4]. Lactic acid bacteria (LAB) and bifidobacteria are the most widespread types of microbes used as probiotics; but certain yeasts and bacilli may also be categorized as probiotics $[2,5]$.

The immune system includes a complex array of cells and molecules, which interact to provide protection from challenge by eradicating all elements

*Address correspondence to this author at the Food Science and Technology, Shahid Sardari Institute, Ministry of Jehad Agriculture, Tabriz, I.R. Iran; Tel: +98 413 3357581; Fax: +98 413 3340634; E-mail: Tabrizu1986@yahoo.com perceived as foreign. The immune system consists of innate and acquired components. The innate immune responses constitute the first line of host defense and comprise a set of resistance mechanisms that are nonspecific to a given pathogen; it plays its role exclusively by phagocytosis. Unlike the innate immune system, the adaptive immunity demonstrates a high level of specificity and memory. Cellular and humoral immunity are the major components of the adaptive immune system [6]. The innate and adaptive immune systems are highly integrated and interdependent. In addition to being a pre-requisite for adaptive immunity, the innate immune response is responsible for the detection and elimination of pathogens [7].

Microbiota of the gastrointestinal tract has an important impact on the anatomical, physiological and immunological development of the host. It stimulates the immune system to react quickly to infection with pathogens and by bacterial antagonism it inhibits the colonization of the gut by harmful or pathogenic 
bacteria [5, 8]. Several immunological studies have been performed in the probiotic field using different strains in various models. Recently great attention has been paid to the possibility of using probiotics to enhance immune system function in immunity-related diseases and many clinical trials have been conducted in this regard. The aim of the present article is to review the literature for the immunological potential of probiotics and to highlight the immune-related disorders for the prevention and control of which, probiotics have been applied.

\section{EFFECT OF PROBIOTICS ON IMMUNE-RELATED DISEASES}

All the diseases human is affected by are closely implicated with immune system; they are most likely either involved in pathogenesis of the disease or the consequence of the ailment. Immune deficiency and immune hypersensitivity are the two extremities of the spectrum of immune related diseases, which have been widely studied in connection with probiotics.

\subsection{Deficiency of Immune Function}

Acquired immunodeficiency syndrome (AIDS) is a human immune system disorder caused by the human immunodeficiency virus (HIV) [9]. Transmission of HIV virus generally occurs by introduction of body fluids from an infected person into the body of an uninfected person. A period of rapid viral replication follows, leading to an abundance of virus in the peripheral blood. During primary infection, several million HIV virus particles may exist per milliliter of blood [10]. This response causes a marked drop in the numbers of circulating $\mathrm{CD}_{4}{ }^{+}$T-cells. This acute viremia is associated in almost all patients with the activation of $\mathrm{CD}_{8}{ }^{+}$T-cells, which kill HIV-infected cells, and consequently with antibody production, orseroconversion. The $\mathrm{CD}_{8}{ }^{+} \mathrm{T}$-cell response is thought to be vital in controlling virus levels, which peak and then reduce, as the $\mathrm{CD}_{4}{ }^{+} \mathrm{T}$-cells increase to normal. $\mathrm{A}$ proper $\mathrm{CD}_{8}{ }^{+} \mathrm{T}$-cell response has been associated with slower disease progression and a better prognosis, though it does not eradicate the virus [11].

When $\mathrm{CD}_{4}{ }^{+} \mathrm{T}$-cell numbers decline below 200 cells per $\mu \mathrm{L}$, cell-mediated immunity is lost and infections with a variety of opportunistic microbes develop. The first symptoms often include moderate and unexplained weight loss, recurring respiratory tract infections (such as sinusitis, bronchitis, otitis media, pharyngitis), prostatitis, skin rashes and oral ulcerations [11]. Diarrhea is a common complication in AIDS patients as well. Probiotics due to their capability of hindering pathogenic bacteria have been tried in easing some symptoms of the affected people and enhancing the quality of their lives. Clinical trials in this regard which are so scarce, are presented in Table 1.

\subsection{Over-Sensitivity of Immune System}

The adaptive immune response provides specific resistance against infection with bacteria, viruses, parasites, and fungi. Particularly, it is able to present rapid protection against a constant challenge with the same or a similar foreign organism or toxin. Some immune responses, however, give rise to an extreme or inappropriate reaction; this is usually referred to as hypersensitivity. There are four major types of hypersensitivity; in type (I), allergic reactions are produced through release of particular mediators. In type (II), a cytotoxic action is induced as an antibody is directed against antigen on an individual's own cells (target cell) or foreign antigen. In type (III), immune complexes are deposited in the tissue causing local tissue damage and inflammation; autoimmune disorders are the result of this type of hypersensitivity. In type (IV), antigen-sensitized T-cells secrete lymphokines when encountering the same antigen for the second time which ends in inflammatory reactions [42]. Due to their greater prevalence, this review focuses on autoimmune diseases and allergies and the impact probiotics may have on patients suffering from these disorders.

\subsubsection{Autoimmune Diseases}

The immune system has remarkable diversity and because the repertoire of specificities expressed by the $B$ and T-cell populations is generated randomly, it is bound to include many that are specific for selfcomponents. Thus, the body must establish self and non-self determinants to prevent auto-reactivity. Like all mechanisms self-recognition mechanisms have a risk of dysfunction and several diseases have been identified in which there is autoimmunity due to bountiful production of auto-antibodies and autoreactive T-cells. Autoimmune disorders can be classified into two main subtypes; the target organs in organ-specific diseases commonly include the thyroid, adrenal, stomach, and pancreas; the non-organspecific disorders, often referred to as systemic autoimmune diseases, which include the rheurnatological diseases, characteristically involve the skin, kidney, joints, and muscle. Probiotics have been reported to be beneficial in alleviating the symptoms of a number of autoimmune disorders. Inflammatory 
Table 1: Effects of Probiotic Supplementation on Immune Related Diseases

\begin{tabular}{|c|c|c|c|c|c|c|c|}
\hline $\begin{array}{l}\text { immune- } \\
\text { related } \\
\text { diseases }\end{array}$ & Type & Carrier & Strain & Dose & Duration & Healthy effect & Ref. \\
\hline \multirow{3}{*}{ Deficiency } & AIDS & Formula & $\begin{array}{c}\text { B. bifidum \& } \\
\text { S. thermophilus }\end{array}$ & $\begin{array}{c}2.5 \times 10^{10} \\
\text { CFU }\end{array}$ & 8 weeks & $\mathrm{CD} 4 \uparrow$ & $\begin{array}{c}\text { (Trois, et al., 2007) } \\
{[12]}\end{array}$ \\
\hline & AIDS & $\begin{array}{c}\text { Not } \\
\text { mentioned }\end{array}$ & L. plantarum & $\begin{array}{c}\text { Not } \\
\text { mentioned }\end{array}$ & 2 weeks & Shortened acute diarrhea & $\begin{array}{c}\text { (Cunningham- } \\
\text { Rundles, et al., 2000) } \\
\text { [13] }\end{array}$ \\
\hline & AIDS & yogurt & $\begin{array}{l}\text { L. rhamnosus } \\
\text { \& L. reuteri }\end{array}$ & $2.5 \times 10^{12} \mathrm{CFU}$ & $15-30$ days & $\mathrm{CD} 4 \uparrow$ & $\begin{array}{c}\text { (Anukam, et al., } \\
\text { 2008) [15] }\end{array}$ \\
\hline \multirow{11}{*}{$\begin{array}{l}\text { Over- } \\
\text { sensitivity }\end{array}$} & CD & Bag & Lactobacillus. GG & $1.2 \times 10^{10} \mathrm{CFU}$ & 12 months & $\begin{array}{l}\text { endoscopic recurrence at } \\
\text { one year was not } \\
\text { prevented and severity of } \\
\text { recurrent lesions was not } \\
\text { reduced }\end{array}$ & $\begin{array}{l}\text { (Prantera, et al., } \\
\text { 2002) [18] }\end{array}$ \\
\hline & Pouchitis & Packet & VSL3 & $9 \times 10^{11} \mathrm{CFU}$ & $\begin{array}{l}1 \text { year after } \\
\text { colitis } \\
\text { surgery }\end{array}$ & $\begin{array}{l}\text { The onset of acute } \\
\text { pouchitis was prevented } \\
\text { probiotic group }\end{array}$ & $\begin{array}{l}\text { (Gionchetti, et al., } \\
\text { 2003) [19] }\end{array}$ \\
\hline & Pouchitis & Capsule & Lactobacillus. GG & $1-2 \times 10^{10} \mathrm{CFU}$ & 3 months & $\begin{array}{c}\text { Clinical or endoscopic } \\
\text { response was not } \\
\text { improved }\end{array}$ & $\begin{array}{c}\text { (Kuisma, et al., 2003) } \\
{[20]}\end{array}$ \\
\hline & UC & $\begin{array}{c}\text { Fermented } \\
\text { milk (Vifit) }\end{array}$ & Lactobacillus. GG & $1.4 \times 10^{10} \mathrm{CFU}$ & 1 years & $\begin{array}{c}\text { The onset on pouchitis } \\
\text { was delayed }\end{array}$ & $\begin{array}{c}\text { (Gosselink, et al., } \\
\text { 2004) [21] }\end{array}$ \\
\hline & $C D$ & Capsule & Lactobacillus. GG & $2 \times 10^{9} \mathrm{CFU}$ & 6 months & $\begin{array}{l}\text { Mmedically induced } \\
\text { remissionwas not } \\
\text { maintained or induced }\end{array}$ & $\begin{array}{c}\text { (Schultz, et al., 2004) } \\
{[25]}\end{array}$ \\
\hline & CD & Capsule & Lactobacillus. GG & $10^{10} \mathrm{CFU}$ & 24 months & $\begin{array}{l}\text { Treatment didn't prolong } \\
\text { time to relapse }\end{array}$ & $\begin{array}{c}\text { (Bousvaros, et al., } \\
\text { 2005) [26] }\end{array}$ \\
\hline & UC & Tablet & Lactobacillus. GG & $1.8 \times 10^{10} \mathrm{CFU}$ & 1 year & $\begin{array}{l}\text { Remission was } \\
\text { maintained and relapse } \\
\text { was prevented }\end{array}$ & $\begin{array}{l}\text { (Zocco, et al., 2006) } \\
{[27]}\end{array}$ \\
\hline & CD & Packet & L. johnsonii & $4 \times 10^{9} \mathrm{CFU}$ & 6 months & $\begin{array}{l}\text { Endoscopic recurrence of } \\
\text { CD was not prevented }\end{array}$ & $\begin{array}{l}\text { (Marteau, et al., } \\
\text { 2006) [28] }\end{array}$ \\
\hline & CD & Sachet & L. Johnsonii & $10^{10} \mathrm{CFU}$ & 3 months & $\begin{array}{l}\text { Early endoscopic } \\
\text { recurrence was not } \\
\text { prevented }\end{array}$ & $\begin{array}{c}\text { (Van Gossum, et al., } \\
\text { 2007) [29] }\end{array}$ \\
\hline & UC & Packet & VSL3 & Weight-based & 1 year & $\begin{array}{l}\text { Remission was } \\
\text { maintained in the } \\
\text { supplemented children }\end{array}$ & $\begin{array}{c}\text { (Miele, et al., 2009) } \\
{[30]}\end{array}$ \\
\hline & UC & Packet & VSL3 & $7.2 \times 10^{12} \mathrm{CFU}$ & 12 weeks & $\begin{array}{l}\text { Supplementation was } \\
\text { safe and effective in } \\
\text { achieving clinical } \\
\text { responses and remissions }\end{array}$ & $\begin{array}{c}\text { (Sood, et al., 2009) } \\
{[31]}\end{array}$ \\
\hline
\end{tabular}


(Table 1). Continued.

\begin{tabular}{|c|c|c|c|c|c|c|c|}
\hline $\begin{array}{l}\text { immune- } \\
\text { related } \\
\text { diseases }\end{array}$ & Type & Carrier & Strain & Dose & Duration & Healthy effect & Ref. \\
\hline & UC & Sachet & VSL3 & $3.6 \times 10^{12} \mathrm{CFU}$ & 8 weeks & $\begin{array}{l}\text { Rectal bleeding was } \\
\text { improved and remission } \\
\text { was reinduced in } \\
\text { relapsing UC patients }\end{array}$ & $\begin{array}{c}\text { (Tursi, et al., 2010) } \\
{[32]}\end{array}$ \\
\hline & UC & Enema & E. coli.Nissle & $1-4 \times 10^{9} \mathrm{CFU}$ & 8 weeks & $\begin{array}{l}\text { A dose-dependent } \\
\text { efficacy of rectal EcN } \\
\text { compared to } \\
\text { placebo was observed }\end{array}$ & $\begin{array}{l}\text { (Matthes, et al., } \\
\text { 2010) [33] }\end{array}$ \\
\hline & UC & $\begin{array}{l}\text { Enema } \\
\text { solution }\end{array}$ & L. reuteri & $10^{10} \mathrm{CFU}$ & 8 weeks & $\begin{array}{l}\text { Mocusal inflammation } \\
\text { improved and mucosal IL- } \\
10 \text { expression significantly } \\
\text { increased whereas IL-1 } \beta \text {, } \\
\text { TNF } \alpha \text { and IL-8 } \\
\text { significantly decreased }\end{array}$ & $\begin{array}{c}\text { (Oliva, et al., 2012) } \\
{[34]}\end{array}$ \\
\hline & RA & Capsule & Lactobacillus. GG & $10^{10} \mathrm{CFU}$ & 1 year & $\begin{array}{l}\text { ILs were not decreased, } \\
\text { but subjective well-being } \\
\text { increased }\end{array}$ & $\begin{array}{l}\text { (Hatakka, et al., } \\
\text { 2003) [35] }\end{array}$ \\
\hline & RA & Caplet & $\begin{array}{l}\text { Bacillus } \\
\text { coagulans }\end{array}$ & $2 \times 10^{9} \mathrm{CFU}$ & 2 months & $\begin{array}{l}\text { patient global assessment } \\
\text { and self-assessed } \\
\text { disability improved and } \\
\text { CRP decreased }\end{array}$ & $\begin{array}{c}\text { (Mandel, et al., 2010) } \\
{[36]}\end{array}$ \\
\hline & RA & Capsule & $\begin{array}{l}\text { L. rhamnosus } \\
\text { and } L \text {. reuteri }\end{array}$ & $4 \times 10^{9} \mathrm{CFU}$ & 3 months & $\begin{array}{l}\text { No clinical improvement } \\
\text { were observed but there } \\
\text { was functional } \\
\text { improvement }\end{array}$ & $\begin{array}{c}\text { (Pineda, et al., 2011) } \\
\text { [37] }\end{array}$ \\
\hline & $A D$ & sachet & L. acidophilus & $3 \times 10^{9} \mathrm{CFU}$ & 6 months & $\begin{array}{l}\text { did not reduce the risk of } \\
A D \text { in high-risk infants }\end{array}$ & $\begin{array}{c}\text { (Taylor, et al., 2007) } \\
{[38]}\end{array}$ \\
\hline & $A D$ & powder & $\begin{array}{l}\text { L. rhamnosus \& } \\
\text { L. reuteri }\end{array}$ & $0.5 \times 10^{10} \mathrm{CFU}$ & 6 weeks & $\begin{array}{c}\text { significant changes in the } \\
\text { production of the } \\
\text { cytokines IL-2, IL-4, IL-10, } \\
\text { or IFN-y } \\
\text { in conclusion they have } \\
\text { was beneficial in the } \\
\text { management of AD }\end{array}$ & $\begin{array}{l}\text { (Rosenfeldt, et al., } \\
\text { 2003) [39] }\end{array}$ \\
\hline & Allergy & yogurt & $\begin{array}{l}\text { L. gasseri \& } \\
\text { L. coryniformis }\end{array}$ & $2 \times 10^{8} \mathrm{CFU}$ & 3 months & CD4/CD25 $\uparrow$ & $\begin{array}{c}\text { (Martínez-Cañavate, } \\
\text { et al., 2009) [40] }\end{array}$ \\
\hline & Allergy & capsules & L. rhamnosus GG & $5 \times 10^{9} \mathrm{CFU}$ & 4 weeks & IFN-Y $\uparrow$ & $\begin{array}{l}\text { (Pohjavuori, et al., } \\
\text { 2004) [41] }\end{array}$ \\
\hline
\end{tabular}

bowel disease (IBD), type (I) diabetes mellitus and rheumatoid arthritis are amongst disorders most studied in this regard [43].

\subsubsection{Probiotics and IBD}

Inflammatory bowel disease (IBD) includes two distinct diseases; Crohn's disease (CD) and ulcerative colitis (UC), both of which are among chronic disorders but have fairly different pathogeneses, underlying inflammatory profile, symptoms and treatment approaches. UC is basically restricted to the colon and/or rectum and is characterized by inflammation and superficial ulceration of the colonic mucosa. On the other hand, $C D$ occurs as skip lesions in any section of the intestinal tract and is characterized by transmural granulomatous inflammation. Pouchitis is another disorder which results from complex ileal pouch-anal anastmosis (IPAA) surgery for UC. It is crucial to note that UC is a Th2 immune response while CD is chiefly a Th1 driven immune response. The precise etiology of IBD is unidentified. Based on current evidence it is proposed to be a result of dysregulated immune response to particular enteric microbiota in genetically susceptible persons. Although a variety of microorganisms and their products have been identified in inflamed tissues of IBD patients, no specific microbe has been proven to cause IBD. However, there is tremendous evidence that the initiation and 
perpetuation of the disease is strongly affected by the intestinal microbiota. This lately attained knowledge has encouraged researchers to explore the effects of manipulating intestinal microbiota and restoring immune system homeostasis on IBD progress. Several studies have examined the possibly of probiotic supplementation in the prevention and/or treatment of diverse inflammatory bowel disorders [6, 44]. The available clinical evidence for the use of probiotics in the treatment of IBD is summarized in Table 1.

\subsubsection{Probiotics and Type (I) Diabetes Mellitus}

Diabetes mellitus (DM) is a main cause of morbidity and mortality in the world. Type (I) diabetes which accounts for $1-10 \%$ of cases is the consequence of autoimmune destruction of pancreatic B-cells. The suggested mechanism for this is over-production of pro-inflammatory cytokines (such as IL-1 $\beta$, TNF $\alpha$ and IFNY). Up-regulation of IL-10 has been shown to protect B-cells against this destruction [45]. To date, only a small number of studies have investigated the anti-diabetic effects of probiotics [46]. To the best of our knowledge, no clinical trials have been performed in this regard, thus far.

\subsubsection{Probiotics and Rheumatoid Arthritis}

Rheumatoid arthritis (RA) is characterized by chronic synovitis and causes stiffness, pain, loss of mobility and progressive erosion of the joints. It usually involves multiple joints symmetrically. Hand and wrists are the most commonly affected joints, but the elbows, neck, shoulders, hips, knee, and feet may also be influenced. Extra-articular symptoms of RA can include development of nodules under the skin (especially at the elbows), lymphadenopathy, vasculitis and even peripheral neuropathy. Although the etiology of RA is not fully understood yet, increasing evidence suggests that $\mathrm{CD}_{4}{ }^{+}$T-cells, which display a principally $\mathrm{Th} 1$ pattern of cytokine expression, have an important role in the pathogenesis of the disease [6]. Blockade of IL12 and/or TNF- $\alpha$ has been revealed to reduce progression of collagen induced arthritis in mice [47] and results in significant clinical improvement in RA patients [48]. In Table 1, clinical trials performed on the effects of probiotics on rheumatoid arthritis are summarized.

\subsubsection{Allergic Diseases}

Allergy is a hypersensitivity disorder of the immune system. Allergic reactions occur when a person's immune system reacts to normally benign substances in the environment. These reactions are acquired, predictable, and fast. Allergic reactions are characteristic because of excessive activation of mast cells and basophile by immunoglobulin E [49]. This reaction results in an inflammatory response which can range from uncomfortable to hazardous [50]. The balance between Th1 and Th2 cytokine production can determine the direction and outcome of an immune response; allergic reactions are the result of abnormal response of Th2 type [51].

The usual treatment of this disease consists of removing the incriminated antigen of the food source (elimination diets), which may prove very inconvenient when put into practice. In addition, immunotherapy and manipulation of the gut microbiota and mucosa can be attempted [52]. Probiotic bacteria have been shown to efficiently down-regulate inflammation associated with hypersensitivity reactions in patients with atopic eczema and food allergy [53, 54]. Probiotics may enhance endogenous barrier mechanisms of the gut and alleviate intestinal inflammation, providing a helpful tool for treating food allergy [53]. The most recent clinical trials in which allergic patients were supplemented with probiotics are summarized in Table 1.

\section{CONCLUSION}

Gut microbiota plays a major role in regulation and stimulation of immune system. Imbalances in the context of these microbes can either be the cause or the consequence of a wide range of diseases. Probiotics, due to their capability of increasing the beneficial bacteria ratio in the intestines, have been tried in several immune related disorders, particularly deficiency (AIDS) and oversensitivity (autoimmune disease and allergy) the immune responses, in attempt to prevent the disease or alleviate the symptoms of the existing ailment. The results from the studies performed in this regard, indicate that probiotics can be most effective in subjects whose immune responses are less than normal at baseline. Besides, the strain administered and its dosage can affect the results of the investigations as well. An interesting point to take into account is that a particular strain may exert different effects on the subjects' immune function in different populations which emphasizes the importance of the physiologic status of the consumers on the benefits they may draw from the probiotic intervention; this is the reason probiotics are claimed to be good regulators of immune system.

\section{ACKNOWLEDGEMENT}

We sincerely thank Student Research Committee, Tabriz University of Medical Sciences for their financial support. We declare herein that we have no conflict of interests. 


\section{REFERENCES}

[1] Savage DC. Factors involved in colonization of the gut epithelial surface. American Journal of Clinical Nutrition 1978; 31(10): 131-135.

[2] Water JV, Naiyanetr P. Yogurt and Immunity, The Health Benefits of Fermented Milk Products That Contain Lactic Acid Bacteria. Handbook of Fermented Functional Foods, (Farnworth ER, ed.^eds.), CRC Press, London 2003; pp. 130-155.

[3] Homayouni A. Letter to the editor. Food Chemistry 2009; 114: 1073.

http://dx.doi.org/10.1016/j.foodchem.2008.10.012

[4] Homayouni A, Akbarzadeh F, Vaghef Mehrbani E. Which are more important: Prebiotics or probiotics? Journal of Nutrition 2012; 28: 1196-1197. http://dx.doi.org/10.1016/j.nut.2012.03.017

[5] Homayouni A, Azizi A, Ehsani MR, Yarmand MS, Razavi SH. Effect of microencapsulation and resistant starch on the probiotic survival and sensory properties of synbiotic ice cream. Food Chemistry 2012; 111: 50-55. http://dx.doi.org/10.1016/j.foodchem.2008.03.036

[6] Gill HS, Grover S, Batish VK, Gill P. Immunological effects of probiotics and their significance to human health. Prebiotics and probiotics science and technology, (Charalampopoulos D, Rastall RA, ed. eds.), pp. Springer, Berlin 2009; 901-948. http://dx.doi.org/10.1007/978-0-387-79058-9 23

[7] Haddad PS, Azar GA, Groom S, Boivin M. Natural health products, modulation of immune function and prevention of chronic diseases. Evidence-Based Complementary and Alternative Medicine 2005; 2: 513-520. http://dx.doi.org/10.1093/ecam/neh125

[8] Cebra JJ. Influences of microbiota on intestinal immune system development. American Journal of Clinical Nutrition 1999; 69: 1046-1051.

[9] Sepkowitz KA. AIDS-the first 20 years. The New England Journal of Medicine 2001; 344: 1764-1772.

http://dx.doi.org/10.1056/NEJM200106073442306

[10] Piatak MJ, Saag MS, Yang LC, Clark SJ, Kappes JC, Luk KC, Hahn BH, Shaw GM, Lifson JD. High levels of HIV-1 in plasma during all stages of infection determined by competitive PCR. Science 1993; 259: 1749-1754.

http://dx.doi.org/10.1126/science.8096089

[11] Pantaleo G, Demarest JF, Schacker T, et al. The qualitative nature of the primary immune response to HIV infection is a prognosticator of disease progression independent of the initial level of plasma viremia. Proceedings of the National Academy of Sciences 1997; 94: 254-258.

http://dx.doi.org/10.1073/pnas.94.1.254

[12] Trois L, Cardoso EM, Miura E. Use of Probiotics in HIVinfected Children: A Randomized Double-blind Controlled Study. Journal of Tropical Pediatrics 2007; 54: $19-24$. http://dx.doi.org/10.1093/tropej/fmm066

[13] Cunningham-Rundles S, Ahrne S, Bengmark S, et al. Probiotics and Immune Response. Gastroenterology 2000; 95: 22-25.

[14] Irvine SL, Hummelen R, Hekmat S. Probiotic yogurt consumption may improve gastrointestinal symptoms, productivity, and nutritional intake of people living with human immunodeficiency virus in Mwanza, Tanzania. Nutrition Research 2011; 31: 875-881. http://dx.doi.org/10.1016/j.nutres.2011.10.005

[15] Anukam KC, Osazuwa EO, Osadolor HB, Bruce AW, Reid G. Yogurt Containing Probiotic Lactobacillus rhamnosus GR1and L. reuteri RC-14 Helps Resolve Moderate Diarrhea and Increases CD4 Count in HIVIAIDS Patients. Journal of Clinical Gastroenterology 2008; 42: 239-243.

[16] Gionchetti P, Rizzello F, Venturi A, Campieri M. Probiotics in infective diarrhea and inflammatory bowel diseases. Journal Gastroenterol Hepatol 2000; 15: 489-493. http://dx.doi.org/10.1046/j.1440-1746.2000.02162.x
[17] Guslandi M, Mezzi G, Sorghi M, Testoni PA. Saccharomyces boulardii in maintenance treatment of Crohn's disease. Digestive Diseases and Sciences 2000; 45: 1462-1464. http://dx.doi.org/10.1023/A:1005588911207

[18] Prantera C, Scribano ML, Falasco G, Andreoli A, Luzi C. Ineffectiveness of probiotics in preventing recurrence after curative resection for Crohn's disease: a randomized controlled trial with Lactobacillus GG. Inflammation and Inflammatory Bowel Disease 2002; 51: 405-409. http://dx.doi.org/10.1136/gut.51.3.405

[19] Gionchetti P, Rizzello F, Helwig U, Venturi A, Lammers KM, Brigidi P, Vitali B, Poggioli G, Miglioli M, Campieri M Prophylaxis of Pouchitis Onset With Probiotic Therapy: A Double-Blind, Placebo-Controlled Trial. The American Gastroenterological Association 2003; 124: 1202-1209. http://dx.doi.org/10.1016/s0016-5085(03)00171-9

[20] Kuisma J, Mentula S, Jarvinen H, Kahri A, Saxelin M, Farkkila M. Effect of Lactobacillus rhamnosus GG on ileal pouch inflammation and microbial flora. Alimentary Pharmacology \& Therapeutics 2003; 17: 509-515. http://dx.doi.org/10.1046/j.1365-2036.2003.01465.x

[21] Gosselink MP, Schouten WR, van Lieshout LMC, Hop WCJ, Laman JD, Embden JGHR. Delay of the First Onset of Pouchitis by Oral Intake of the probiotic strain Lactobacillus rhamnosus GG. Diseases of the Colon \& Rectum 2004; 47: 876-884. http://dx.doi.org/10.1007/s10350-004-0525-z

[22] Tursi A, Brandimarte G, Giorgetti GM, Forti G, Modeo ME. Low-dose balsalazide plus a high-potency probiotic preparation is more effective than balsalazide alone or mesalazine in the treatment of acute mild-to-moderate ulcerative colitis. International Medical Journal of Experimental and Clinical Research 2004; 10: 126-131.

[23] Mimura T, Rizzello F, Helwig U, Poggioli G, Schreiber S, Talbot IC, Nicholls RJ, Gionchetti P, Campieri M, Kamm MA. Once daily high dose probiotic therapy (VSL\#3) for maintaining remission in recurrent or refractory pouchitis. Inflammatory Bowel Disease 2004; 53: 108-114.

http://dx.doi.org/10.1136/gut.53.1.108

[24] Kruis W, Frič $P$, Pokrotnieks J, et al. Maintaining remission of ulcerative colitis with the probiotic Escherichia coli Nissle 1917 is as effective as with standard mesalazine. Gut 2004; 53: $1617-1623$.

http://dx.doi.org/10.1136/gut.2003.037747

[25] Schultz M, Timmer A, Herfarth HH, Sartor RB, Vanderhoof J, A, Rath HC. Lactobacillus $G G$ in inducing and maintaining remission of Crohn's disease. BMC Gastroenterology 2004; 4.

[26] Bousvaros A, Guandalini S, Baldassano RN, et al. A Randomized, Double-blind Trial of Lactobacillus GG Versus Placebo in Addition to Standard Maintenance Therapy for Children with Crohn's Disease. Inflammatory Bowel Disease 2005; 11: 833-839.

http://dx.doi.org/10.1097/01.MIB.0000175905.00212.2C

[27] Zocco MA, Zileri dal verme L, Cremonini F, et al. Efficacy of Lactobacillus GG in maintaining remission of ulcerative colitis. Alimentary Pharmacology \& Therapeutics 2006; 23: 1567-1574.

http://dx.doi.org/10.1111/j.1365-2036.2006.02927.x

[28] Marteau $P$, Lémann $M$, Seksik $P$, et al. Ineffectiveness of Lactobacillus johnsonii LA1 for prophylaxis of postoperative recurrence in Crohn's disease: a randomized, double blind, placebo controlled GETAID trial. Inflammatory Bowel Disease 2006; 55: 842-847. http://dx.doi.org/10.1136/gut.2005.076604

[29] Van Gossum A, Dewit O, Louis E, de Hertogh G, Baert F, Fontaine F, DeVos M, Enslen M, Paintin M, Franchimont D. Multicenter randomized-controlled clinical trial of probiotics (Lactobacillus johnsonii, LA1) on early endoscopic recurrence of Crohn's disease after ileo-caecal resection. Inflammatory Bowel Diseases 2007; 13: 135. http://dx.doi.org/10.1002/ibd.20063 
[30] Miele E, Pascarella F, Giannetti E, Quaglietta L, Baldassano RN, Staiano A. Effect of a Probiotic Preparation (VSL\#3) on Induction and Maintenance of Remission in Children With Ulcerative Colitis. American Journal of Gastroenterolgy 2009; 104: 437-443. http://dx.doi.org/10.1038/ajg.2008.118

[31] Sood A, Midha V, Makharia GK, Ahuja V, Singal D, Goswami $\mathrm{P}$, Tandon RK. The Probiotic Preparation, VSL\#3 Induces Remission in Patients With Mild-to-Moderately Active Ulcerative Colitis. Clinical Gastroenterology and Hepatology 2009; 7: 1202-1209. http://dx.doi.org/10.1016/j.cgh.2009.07.016

[32] Tursi A, Brandimarte G, Papa A, et al. Treatment of Relapsing Mild-to-Moderate Ulcerative Colitis With the Probiotic VSL \# 3 as Adjunctive to a Standard Pharmaceutical Treatment: A Double-Blind, Randomized, Placebo-Controlled Study. The American Journal of Gastroenterology 2010; 105: 2218-2227. http://dx.doi.org/10.1038/ajg.2010.218

[33] Matthes H, Krummenerl T, Giensch M, Wolff C, Schulze J. Clinical trial: probiotic treatment of acute distal ulcerative colitis with rectally administered Escherichia coli Nissle 1917 (EcN). BMC Complementary and Alternative Medicine 2010; 10: 1-8.

http://dx.doi.org/10.1186/1472-6882-10-13

[34] Oliva S, Di Nardo G, Ferrari F, Mallardo S, Rossi P, Patrizi G, Cucchiara S, Stronati L. Randomized clinical trial: the effectiveness of Lactobacillus reuteri ATCC 55730 rectal enema in children with active distal ulcerative colitis. Alimentary Pharmacology \& Therapeutics 2012; 35: 327-334. http://dx.doi.org/10.1111/j.1365-2036.2011.04939.x

[35] Hatakka K, Martio J, Korpela M, Herranen M, Poussa T, Laasanen T, Saxelin M, Vapaatalo H, Moilanen E, Korpela R. Effects of probiotic therapy on the activity and activation of mild rheumatoid arthritis-a pilot study. Scandinavian Journal of Rheumatology 2003; 32: 211-215. http://dx.doi.org/10.1080/03009740310003695

[36] Mandel DR, Eichas K, Holmes J. Bacillus coagulans: a viable adjunct therapy for relieving symptoms of rheumatoid arthritis according to a randomized, controlled trial. BMC Complementary and Alternative Medicine 2010; 10: 1-7. http://dx.doi.org/10.1186/1472-6882-10-1

[37] Pineda MA, Thompson SF, Summers K, Leon F, Pope J, Reid G. A randomized, double-blinded, placebo-controlled pilot study of probiotics in active rheumatoid arthritis. Medical Science Monitor 2011; 17: 347-354.

[38] Taylor AL, Dunstan JA, Prescott SL. Probiotic supplementation for the first 6 months of life fails to reduce the risk of atopic dermatitis and increases the risk of allergen sensitization in high-risk children: A randomized controlled trial. American Academy of Allergy, Asthma \& Immunology 2007; 119: 184-191. http://dx.doi.org/10.1016/j.jaci.2006.08.036

[39] Rosenfeldt V, Benfeldt E, Nielsen SD, Michaelsen KF, Jeppesen DL, Valerius NH, Paerregaard A. Effect of probiotic Lactobacillus strains in children with atopic dermatitis. Journal of Allergy Clinical Immunology 2003; 111: 389-395. http://dx.doi.org/10.1067/mai.2003.389

[40] Martínez-Cañavate A, Sierra S, Lara-Villoslada F,Romero J, Maldonado J, Boza J, Xaus J, Olivares M. A probiotic dairy product containing L. gasseri CECT5714 and L. coryniformis CECT5711 induces immunological changes in children suffering from allergy. Pediatr Allergy Immunology 2009; 20: 592-600.

http://dx.doi.org/10.1111/j.1399-3038.2008.00833.x
[41] Pohjavuori E, Viljanen M, Korpela R, Kuitunen M, Tiittanen M, Vaarala O, Savilahti E. Lactobacillus GG effect in increasing IFN-gamma production in infants with cow's milk allergy. Journal of Allergy Clinical Immunology 2004; 114: 131-136. http://dx.doi.org/10.1016/j.jaci.2004.03.036

[42] Roitt IM, Brostoff J, Male DK. Immunology. Gower Medical, London 1998.

[43] Male D, Brostoff J, Roth DB, Roitt I. immunology. Elsevier, Missouri 2006.

[44] Matsumoto S, Hara T, Hori T, Mitsuyama K, Nagaoka M,Tomiyasu N, Suzuki A, Sata M. Probiotic Lactobacillusinduced improvement in murine chronic inflammatory bowel disease is associated with the down-regulation of proinflammatory cytokines in lamina propria mononuclear cells. Clinical and Experimental Immunology 2005; 140: 417-426. http://dx.doi.org/10.1111/j.1365-2249.2005.02790.x

[45] Goudy KS, Burkhardt BR, Wasserfall C, et al. Systemic overexpression of IL-10 induces CD4+CD25+ cell populations in vivo and ameliorates type 1 diabetes in nonobese diabetic mice in a dose-dependent fashion. The Journal of Immunology 2003; 171: 2270-2278. http://dx.doi.org/10.4049/jimmunol.171.5.2270

[46] Ejtahed HS, Mohtadi-Nia J, Homayouni A, Niafar M, AsghariJafarabadi M, Mofid V. Probiotic yogurt improves antioxidant status in type2 diabetic patients. Journal of Nutrition 2012; 28: 539-543.

http://dx.doi.org/10.1016/j.nut.2011.08.013

[47] Butler DM, Anne-Marie Malfait A, Maini RN, Brennan FM, Feldmann M. Anti-IL-12 and anti-TNF antibodies synergistically suppress the progression of murine collageninduced arthritis. European Journal of Immunology 2008; 29: 2205-2212.

http://dx.doi.org/10.1002/(SICl)15214141(199907)29:07<2205::AID-IMMU2205>3.0.CO;2-Z

[48] van Oosterhout M, Levarht EW, Sont JK, Huizinga TW, Toes RE, van Laar JM. Clinical efficacy of infliximab plus methotrexate in DMARD naive and DMARD refractory rheumatoid arthritis is associated with decreased synovial expression of TNFa and IL18 but not CXCL12. Annals of the Rheumatic Diseases 2005; 64: 537-543. http://dx.doi.org/10.1136/ard.2004.024927

[49] Milstein O, Hagin D, Lask A, et al. CTLs respond with activation and granule secretion when serving as targets for T-cell recognition. The American Society of Hematology 2011; 117: 1042-1052. http://dx.doi.org/10.1182/blood-2010-05-283770

[50] Kay $A B$. Overview of 'allergy and allergic diseases: with a view to the future. British Medical Bulletin 2000; 56: 843-864. http://dx.doi.org/10.1258/0007142001903481

[51] Janeway $C$, Travers $P$, Walport $M$, Shlomchik MJ. Immunobiology: The Immune System in Health and Disease. Garland Pub, London 2004.

[52] Dugas B, Mercenier A, Lenoir-Wijnkoop I, Arnaud C, Dugas $\mathrm{N}$, Postaire E. Immunity and probiotics. Immunology Today 1999; 20: 387-390.

http://dx.doi.org/10.1016/S0167-5699(99)01448-6

[53] Majamaa H, Isolauri E. Probiotics: a novel approach in the management of food allergy. Journal of Allergy Clinical Immunology 1997; 99: 179-185. http://dx.doi.org/10.1016/S0091-6749(97)70093-9

[54] Murch SH. Toll of allergy reduced by probiotics. Lancet 2001; 357: 1057-1059. http://dx.doi.org/10.1016/S0140-6736(00)04305-1 